\title{
Sequence-specific Ni(II)-dependent peptide bond hydrolysis in a peptide containing threonine and histidine residues
}

\author{
Artur Krężel ${ }^{1}$, Marios Mylonas², Edyta Kopera ${ }^{3}$ and Wojciech Bal ${ }^{3,4}$ \\ ${ }^{1}$ Department of Preventive Medicine and Community Health, University of Texas Medical Branch, Galveston, \\ USA; ${ }^{2}$ University of Ioannina, Department of Chemistry, Ioannina, Greece; ${ }^{3}$ Institute of Biochemistry and \\ Biophysics, Polish Academy of Sciences, Warszawa, Poland; ${ }^{4}$ Central Institute of Labour Protection-National

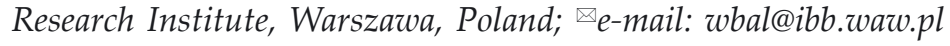

Received: 19 July, 2006; revised: 31 October, 2006; accepted: 02 November, 2006 available on-line: 22 November, 2006

\begin{abstract}
Previously we demonstrated that Ni(II) complexes of Ac-Thr-Glu-Ser-His-His-Lys-NH ${ }_{2}$ hexapeptide, representing residues 120-125 of human histone $\mathrm{H} 2 \mathrm{~A}$, and some of its analogs undergo $\mathrm{E}$ $\mathrm{S}$ peptide bond hydrolysis. In this work we demonstrate a similar coordination and reactivity pattern in $\mathrm{Ni}$ (II) complexes of Ac-Thr-Glu-Thr-His-His-Lys- $\mathrm{NH}_{2}$, its threonine analogue, studied using potentiometry, electronic absorption spectroscopy and HPLC. For the first time we present the detailed temperature and $\mathrm{pH}$ dependence of such $\mathrm{Ni}$ (II)-dependent hydrolysis reactions. The temperature dependence of the rate of hydrolysis yielded activation energy $E_{\mathrm{a}}=92.0 \mathrm{~kJ} \mathrm{~mol}^{-1}$ and activation entropy $\Delta S^{\neq}=208 \mathrm{~J} \mathrm{~mol}^{-1} \mathrm{~K}^{-1}$. The $\mathrm{pH}$ profile of the reaction rate coincided with the formation of the four-nitrogen square-planar Ni(II) complex of Ac-Thr-Glu-Thr-His-His-Lys- $\mathrm{NH}_{2}$. These results expand the range of protein sequences susceptible to $\mathrm{Ni}$ (II) dependent cleavage by those containing threonine residues and permit predictions of the course of this reaction at various temperatures and $\mathrm{pH}$ values.
\end{abstract}

Keywords: nickel(II), peptide bond hydrolysis, complex formation, activation parameters

\section{INTRODUCTION}

We previously discovered $\mathrm{Ni}(\mathrm{II})$-dependent hydrolysis of the Glu-Ser peptide bond in the AcThr-Glu-Ser-His-His-Lys- $\mathrm{NH}_{2}$ hexapeptide, representing residues $120-125$ of the major variant of human histone H2A (Bal et al., 1998). Subsequently, we found that sequence specificity of this reaction was retained in the whole histone $\mathrm{H} 2 \mathrm{~A}$ in vitro (Bal et al., 2000a) and in cell cultures exposed to nickel(II) salts (Karaczyn et al., 2003). Using a series of alanine-substituted hexapeptides we demonstrated that the hydrolysis of the peptide bond preceding the Ser residue occurred in -Xaa-SerYaa-His- sequences, where Xaa was Glu or Ala, and Yaa was His or Ala (Mylonas et al., 2002a). The prior formation of a square-planar Ni(II) complex involving the coordination of amide nitrogens was required for the hydrolysis to occur. A substitution of Ser or His-5 in these hexapeptides with Ala residue abolished the peptide bond hydrolysis completely, although these peptides retained $\mathrm{Ni}$ (II) binding abilities. We also studied the coordination of $\mathrm{Cu}(\mathrm{II})$ ions (Mylonas et al., 2002b) and $\mathrm{Zn}(\mathrm{II})$ ions (Mylonas et al., 2004a) to these peptides and investigated the oxidative reactivity of their $\mathrm{Cu}(\mathrm{II})$ complexes (Kaczmarek et al., 2005). These studies were summarized recently (Mylonas et al., 2005a). Below we present novel results demonstrating that the substitution of the active serine residue with threonine yields peptides equally susceptible to $\mathrm{Ni}(\mathrm{II})$-dependent hydrolysis. For the first time we provide the $\mathrm{pH}$ and temperature dependence of the reaction rate. These results greatly expand our knowledge on $\mathrm{Ni}(\mathrm{II})$ dependent peptide bond cleavage.

Abbreviations: $k^{1}, 1$ st order rate constant; $3 \mathrm{~N}$, three-nitrogen complex; $4 \mathrm{~N}$, four-nitrogen complex. 


\section{MATERIALS AND METHODS}

Peptide synthesis. The peptides Ac-Thr-GluThr-His-His-Lys- $\mathrm{NH}_{2}$ and Ac-Phe-Thr-Glu-Thr-HisHis-Lys-Tyr- $\mathrm{NH}_{2}$ were synthesized in the solid state on an H-linker-chlorotrityl resin (1.5 g per each peptide with the loading capacity $0.5 \mathrm{mmol} / \mathrm{g}$ ) using Fmoc strategy (Fields, 1997; Chan \& White, 2000), with 4- and 8-fold excess of amino acids and coupling agents, respectively. The resin and protected amino acids, Fmoc-Lys(Boc)-OH, FmocHis(Mtt)-OH, Fmoc-Thr(tBu)-OH, Fmoc-Glu(tBu)$\mathrm{OH}$, Fmoc-Phe $(\mathrm{tBu})-\mathrm{OH}$, Fmoc-Tyr $(\mathrm{tBu})-\mathrm{OH}$, and Fmoc-Ser(tBu)-OH were purchased from CBL Chemical, coupling agents, 1-hydroxybenzatriazole (HOBt) and dicyclohexylcarbodiimide (DCC) were from Merck AG, N,N-dimethylformamide (DMF), dichloromethane $(\mathrm{DCM})$, acetic acid $(\mathrm{AcOH})$ and acetonitrile $(\mathrm{MeCN})$ were obtained from Riedel-de Haen, trifluoroacetic acid (TFA), 2,2,2-trifluoroethanol (TFE) and piperidine $N, N$-diisopropylethylamine (DIEA) were from Sigma-Aldrich. Fmoc protecting groups were removed with $20 \%$ piperidine in DMF. The coupling with DCC and HOBt, performed in the presence of 4 -fold excess of DIEA over $4 \mathrm{~h}$, was monitored by the ninhydrin (Keiser) test and TLC. Peptides were terminated with acetic anhydride in DMF containing DIEA. N-terminal acetylated resinbound peptides were cleaved from the resin with $35 \mathrm{ml}$ of 1:2:7 mixture of TFE, AcOH and DCM (by vol.), followed by evaporation under vacuum. The removal of protecting groups was performed in each case by adding $35 \mathrm{ml}$ of 13:5:1:1 mixture of TFA, DCM, TFE and anisol (by vol.) and incubating for $24 \mathrm{~h}$ at room temperature. The resin was removed by filtration and washed with 50\% TFA in DCM (2 $\times 2 \mathrm{ml}$ ), which was combined with the filtrate. The filtrate was then poured into $150 \mathrm{ml}$ of cold ether, yielding a precipitate, which was subsequently dissolved in water and lyophilized to give about 300 mg of raw product as a powder. Peptides were purified using HP series 1100 HPLC system (HewlettPackard) on a preparative Alltech Apollo C18 column $(22 \mathrm{~mm} \times 250 \mathrm{~mm}, 5 \mu \mathrm{m})$ eluting with $0.1 \%$ TFA/water (A) and $0.1 \% \mathrm{TFA} / 90 \% \mathrm{MeCN} /$ water (B), using a linear gradient from 0 to $100 \%$ of $\mathrm{B}$ over 60 min at a flow rate of $1 \mathrm{ml} / \mathrm{min}$, with detection at 220 $\mathrm{nm}$. The identities and purities of peptides were confirmed using mass spectrometry, on a TSQ 700 ESIMS spectrometer (Finnigan MAT). The $\mathrm{m} / \mathrm{z}$ values found (calculated) of $(\mathrm{M}+\mathrm{H})^{+}$ions were: 793.2 (793.4) and 1103.5 (1103.4) for Ac-Thr-Glu-Thr-His-His-Lys$\mathrm{NH}_{2}$ and Ac-Phe-Thr-Glu-Thr-His-His-Lys-Tyr- $\mathrm{NH}_{2}$, respectively. The purities of the final peptide samples were additionally controlled by ${ }^{1} \mathrm{H} \mathrm{NMR}$, on an Inova $400 \mathrm{MHz}$ spectrometer (Varian). The synthesis of Ac-Thr-Glu-Ser-His-His-Lys-NH ${ }_{2}$, Ac-Thr-Ala-Ser-
His-His-Lys- $\mathrm{NH}_{2}$, and Ac-Thr-Glu-Ser-Ala-His-Lys$\mathrm{NH}_{2}$ peptides was described previously (Mylonas et al., 2002b).

Potentiometry. Potentiometric titrations of Ac-Thr-Glu-Thr-His-His-Lys- $\mathrm{NH}_{2}$ and its $\mathrm{Ni}(\mathrm{II})$ complexes in the presence of $0.1 \mathrm{M} \mathrm{KNO}_{3}$ were performed under a purified argon atmosphere at $25^{\circ} \mathrm{C}$ within the $\mathrm{pH}$ range of 2.8 to 11.5 on a Molspin automatic titrator, with $0.1 \mathrm{M} \mathrm{NaOH}$ as titrant. Changes in $\mathrm{pH}$ were monitored with a combined glass- $\mathrm{Ag} /$ $\mathrm{AgCl}$ electrode (InLab 422, Mettler-Toledo), calibrated daily in hydrogen ion concentrations by titrations of $4 \mathrm{mM} \mathrm{HNO}$ solutions in $96 \mathrm{mM} \mathrm{KNO}_{3}$ (Irving et al., 1967). Sample volumes of 1.5-2.0 ml, peptide concentrations of $1 \mathrm{mM}$ and peptide-to-Ni(II) molar ratios of 1.2-1.8 were used. The data were analyzed using SUPERQUAD program (Gans et al., 1985). Standard deviations of constants computed by SUPERQUAD refer to random errors.

Spectroscopic studies. UV-Vis spectra of $\mathrm{Ni}(\mathrm{II})$ complexes of Ac-Thr-Glu-Thr-His-His-Lys- $\mathrm{NH}_{2}$ were recorded on a Cary 50 Bio spectrophotometer, using peptide and $\mathrm{Ni}(\mathrm{II})$ concentrations of $1.5 \mathrm{mM}$. For $\mathrm{pH}$ values below 7.0 the samples were kept at room temperature and the spectra were recorded at $25^{\circ} \mathrm{C}$. At higher $\mathrm{pH}$ values the samples were kept on ice between measurements in order to quench the hydrolysis reaction and allow for the reliable recording of spectra of the unhydrolyzed initial complexes.

Determination of rate constants. Samples containing $1 \mathrm{mM}$ peptide and $1 \mathrm{mM} \mathrm{Ni}$ (II) in $50 \mathrm{mM}$ phosphate buffer at $\mathrm{pH}$ values between 7.0 and 11.0 were incubated at $25^{\circ} \mathrm{C}$ for up to five days. In separate experiments, analogous samples at $\mathrm{pH} 9.5$ were incubated at temperatures between 10 and $75^{\circ} \mathrm{C}$. In either case, $20 \mu \mathrm{l}$ aliquots of reaction mixtures were collected, mixed with $180 \mu \mathrm{l}$ of $0.1 \mathrm{M} \mathrm{H}_{3} \mathrm{PO}_{4}$ and stored on ice until analyzed (within $3 \mathrm{~h}$ ) on a series 1100 HPLC (Hewlett Packard) with a Hypersil BDC C18 analytical column, $4.6 \times 250 \mathrm{~mm}$ (Merck). The substrate and the products were separated isocratically using $50 \mathrm{mM}$ phosphate buffer in $10 \% \mathrm{MeOH}$, $\mathrm{pH} 2.6$, at the flow rate of $1 \mathrm{ml} / \mathrm{min}$ and detection at $200 \mathrm{~nm}$. The rate constants were determined by fitting the integrals of substrate and product peaks to the 1st order rate law.

\section{RESULTS AND DISCUSSION}

\section{Protonation and complex formation}

Table 1 presents the protonation and $\mathrm{Ni}(\mathrm{II})$ stability constants of the Ac-Thr-Glu-Thr-His-HisLys- $\mathrm{NH}_{2}$ peptide, Fig. 1 presents selected UV-Vis spectra, while Fig. 2 compares the potentiometry- 
Table 1. Cumulative and stepwise protonation and $\mathrm{Ni}(\mathrm{II})$ binding constants for Ac-Thr-Glu-Thr-His-His-Lys- $\mathrm{NH}_{2}$, determined at $25^{\circ} \mathrm{C}$ and $I=0.1$ $\mathrm{M}\left(\mathrm{KNO}_{3}\right)$.

Standard deviations of the last digit are given in parentheses. The previously published data for the analogous Ac-Thr-Glu-Ser-His-His-Lys- $\mathrm{NH}_{2}$ system (Mylonas et al., 2002a) are included for comparison.

\begin{tabular}{lcccr}
\hline Species & \multicolumn{2}{c}{ Ac-TETHHK-NH } & & Ac-TESHHK-NH \\
& $\log \beta^{a}$ & $\mathrm{pK}_{\mathrm{a}}^{b}$ & $\log \beta^{a}$ & $\mathrm{pK}_{\mathrm{a}}^{b}$ \\
\hline $\mathrm{HL}$ & $10.465(6)$ & 10.47 & 10.28 & 10.28 \\
$\mathrm{H}_{2} \mathrm{~L}^{+}$ & $17.178(7)$ & 6.71 & 17.06 & 6.78 \\
$\mathrm{H}_{3} \mathrm{~L}^{2+}$ & $23.022(8)$ & 5.84 & 22.96 & 5.90 \\
$\mathrm{H}_{4} \mathrm{~L}^{3+}$ & $26.983(9)$ & 3.96 & 26.81 & 3.85 \\
$\mathrm{NiHL}^{2+}$ & $14.24(2)$ & & 14.04 & \\
$\mathrm{NiH}_{-1} \mathrm{~L}$ & $-1.90(2)$ & $8.07^{c}$ & -2.16 & $8.10^{c}$ \\
$\mathrm{NiH}_{-2} \mathrm{~L}^{-}$ & $-10.88(2)$ & 8.98 & -11.52 & 9.36 \\
$\mathrm{NiH}_{-3} \mathrm{~L}^{2-}$ & $-21.71(3)$ & 10.83 & -22.80 & 11.28 \\
\hline
\end{tabular}

${ }^{a} \beta=\left[\mathrm{Ni}_{i} \mathrm{H}_{j} \mathrm{~L}_{k}\right] /\left([\mathrm{Ni}]^{i}[\mathrm{H}]^{[}[\mathrm{L}]^{k}\right) ;{ }^{b} \mathrm{pK}_{\mathrm{a}}=\log \beta\left\{\mathrm{Ni}_{i} \mathrm{H}_{j+1} \mathrm{~L}_{k}\right\}-\log \beta\left\{\mathrm{Ni}_{i} \mathrm{H}_{j} \mathrm{~L}_{k}\right\} ;{ }^{c}$ average value for two simultaneous deprotonations

based complex species distribution with UV-Vis spectral parameters characteristic for octahedral and square-planar complexes, $\mathrm{A}_{638}$ and $\mathrm{A}_{453}$, respectively, demonstrating the correctness of potentiometric data analysis. Table 2 provides the UV-Vis spectral parameters, calculated for individual complexes with the use of the potentiometric species distribution. The identical sets of potential $\mathrm{Ni}$ (II) binding sites, identical complex stoichiometries and very similar binding constant values (compared in Table 1) and UV-Vis spectroscopic profiles (compared in Table 2) indicate that analogous complexes were formed for the Ac-Thr-Glu-Thr-His-His-Lys- $\mathrm{NH}_{2}$ peptide and for its serine analog, Ac-Thr-Glu-Ser-His-HisLys- $\mathrm{NH}_{2}$. Therefore, according to studies on the latter one (Bal et al., 1998, Mylonas et al., 2002a), the high-spin $\mathrm{NiHL}^{2+}$ complex contains the $\mathrm{Ni}(\mathrm{II})$ ion coordinated to nitrogens of both imidazole rings and to the Glu side chain carboxylate. The release of two hydrogen ions from this species yields the $\mathrm{NiH}_{-1} \mathrm{~L}$ complex, which involves the $\mathrm{Ni}$ (II) coordination to one imidazole and two deprotonated amide nitrogens ( $3 \mathrm{~N}$ complex). The UV-Vis spectroscopic parameters of this complex (Table 2) indicate that

Table 2. UV-Vis spectroscopic parameters of $\mathrm{Ni}$ (II) complexes of Ac-Thr-Glu-Thr-His-His-Lys- $\mathrm{NH}_{2}$.

Spectral shoulders are denoted by sh.

\begin{tabular}{lcc}
\hline Species & $\lambda_{\text {max }}(\mathrm{nm})$ & $\varepsilon\left(\mathrm{M}^{-1} \mathrm{~cm}^{-1}\right)$ \\
\hline $\mathrm{NiHL}^{2+}$ & $\mathrm{sh} 725$ & 2.0 \\
& 638 & 3.9 \\
& 390 & 14.0 \\
$\mathrm{NiH}_{-1} \mathrm{~L}$ & $\mathrm{sh} 560$ & 4.4 \\
& 443 & 28.5 \\
& $\mathrm{sh} 382$ & 16.7 \\
$\mathrm{NiH}_{-2} \mathrm{~L}^{-}$ & 453 & 96 \\
$\mathrm{NiH}_{-3} \mathrm{~L}^{2-}$ & 457 & 147 \\
\hline
\end{tabular}

this species is a mixture of high- and low-spin complexes sharing the same stoichiometry. Such phenomena are typical for $\mathrm{Ni}(\mathrm{II})$ complexes. Judging from the data obtained previously for similar complexes, the participation of both forms in the $\mathrm{NiH}_{-1} \mathrm{~L}$ species is approximately equal (Mylonas et al., 2002a). The next species, $\mathrm{NiH}_{-2} \mathrm{~L}^{-}$is formed upon the deprotonation and coordination of the third amide nitrogen (4N complex). The final $\mathrm{NiH}_{-3} \mathrm{~L}^{2-}$ complex is formed upon the Lys amine deprotonation, which does not affect the binding mode, but influences spectroscopic properties of $\mathrm{Ni}(\mathrm{II})$. The parameters of spectra of $\mathrm{NiH}_{-2} \mathrm{~L}^{-}$and $\mathrm{NiH}_{-3} \mathrm{~L}^{3-}$ complexes are consistent with typical square-planar structures of low-spin $\mathrm{Ni}(\mathrm{II})$. The molar absorption coefficient of the $d-d$ band of the $\mathrm{NiH}_{-3} \mathrm{~L}^{3-}$ complex is higher than that of the $\mathrm{NiH}_{-2} \mathrm{~L}^{2-}$ complex by about $50 \%$. The increases of $\varepsilon$ values accompanying Lys deprotonations in complexes of related peptides were smaller (Mylonas et al., 2002a). This difference might be due to the low temperature at which the samples were incubated here, which can be expected to augment intramolecular electrostatic interactions between side chains, and thereby sensitize the $\mathrm{Ni}(\mathrm{II})$ ion to Lys charge. Previously, we calculated the distribution of electrostatic potential in the structurally related $\mathrm{N}$-terminal $\mathrm{Ni}(\mathrm{II})$ complex of protamine HP2 and demonstrated that it provides a template for such interactions with amino-acid side chains (Bal et al., 2000b).

The presence of His residues in positions 4 and 5 may result in the formation of two different square-planar complexes, one at the -Asp-Thr-
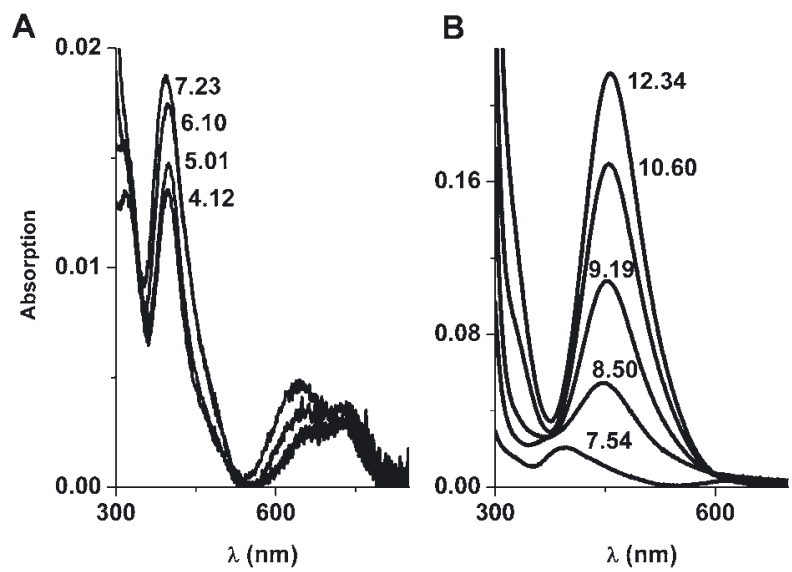

Figure 1. Selected UV-Vis spectra for Ac-Thr-Glu-ThrHis-His-Lys- $\mathrm{NH}_{2}$ peptide and $\mathrm{Ni}(\mathrm{II})$ ions, both at 1.5 $\mathrm{mM}$, in the ranges of existence of high-spin (A) and lowspin (B) complexes.

The $\mathrm{pH}$ values are indicated near the respective peaks. 


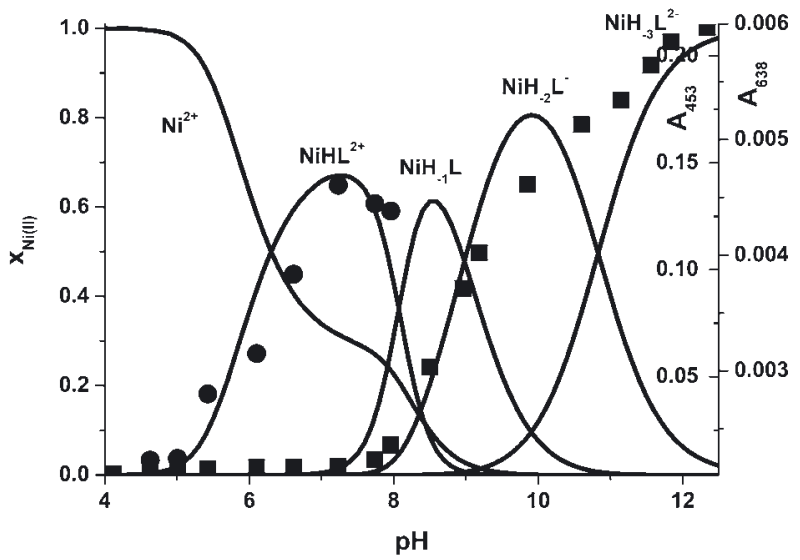

Figure 2. The species distribution for the Ac-Thr-GluThr-His-His-Lys- $\mathrm{NH}_{2}$ peptide and $\mathrm{Ni}$ (II) ions at $25^{\circ} \mathrm{C}$, both at $1.5 \mathrm{mM}$, with values of $\mathrm{A}_{638}(\bullet)$ and $\mathrm{A}_{453}$ (घ) overlaid.

His- sequence (anchored at His-4), and another at the -Thr-His-His- sequence (anchored at His-5). As discussed previously (Mylonas et al., 2002a), the simultaneous coordination of both His imidazoles is not compatible with the square-planar structure. The NMR data for the Ac-Thr-Ala-Ser-His-His-Lys- $\mathrm{NH}_{2}$ peptide presented there suggest a preference for the latter option, which is most likely retained for all similar peptides, including the one studied here.

As shown in Table 1, the threonine analog binds $\mathrm{Ni}(\mathrm{II})$ a little more strongly than the serine analog. In particular, the $\mathrm{pK}_{\mathrm{a}}$ of formation of the four nitrogen $(4 \mathrm{~N})$ complex of the threonine peptide is lower by $0.38 \mathrm{log}$ units than that of the serine peptide. This difference can be explained by an additional shielding of amide nitrogens from water molecules, provided by the methyl group of the threonine side chain. The shielding by bulky substitutents was demonstrated previously to protect such

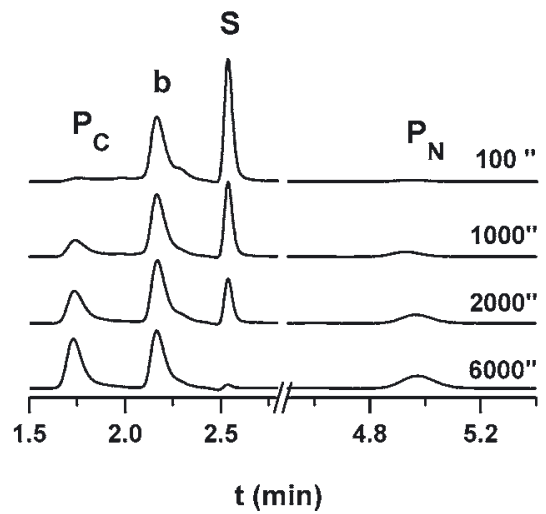

Figure 3. Typical chromatograms of the sample containing $1 \mathrm{mM} \mathrm{Ni(II)}$ and $1 \mathrm{mM}$ Thr-Glu-Thr-His-His-Lys$\mathrm{NH}_{2}$ peptide, incubated at $25^{\circ} \mathrm{C}$ and $\mathrm{pH} 9.5$ for time periods indicated on the graph, in a $50 \mathrm{mM}$ phosphate buffer.

$\mathrm{P}_{\mathrm{C}^{\prime}}$ Thr-His-His-Lys- $\mathrm{NH}_{2}$ peptide, $\mathrm{P}_{\mathrm{N}^{\prime}}$ Ac-Thr-Glu peptide; $\mathrm{S}$, Thr-Glu-Thr-His-His-Lys- $\mathrm{NH}_{2}$ peptide, $\mathrm{b}$, unidentified buffer component. complexes from reprotonation of amide nitrogens leading to $\mathrm{Ni}(\mathrm{II})$ dissociation (Raycheba \& Margerum, 1980; Bal et al., 1996).

Peptide bond hydrolysis. Figure 3 shows a selection of typical chromatograms of reaction mixtures containing equimolar $\mathrm{Ni}$ (II) and Ac-Thr-GluThr-His-His-Lys- $\mathrm{NH}_{2}$, at $1 \mathrm{mM}$, following incubation in a $50 \mathrm{mM}$ phosphate buffer for various times. The identities of individual peaks were confirmed by ESI-MS. Chromatographic results confirmed the absolute sequence specificity of peptide bond hydrolysis in the system studied, at all $\mathrm{pH}$ values.

The $\mathrm{pH}$ dependence of the 1st order rate constant $\left(k^{1}\right)$ for hydrolysis is shown in Fig. 4. The comparison of this profile with $\mathrm{pH}$ profiles of formation of $3 \mathrm{~N}+4 \mathrm{~N}$ and $4 \mathrm{~N}$ complexes confirms the strict requirement of the latter complex, which contains the $\mathrm{Ni}$ (II) ion bonded to the imidazole nitrogen- 1 of His-5 and three preceding amide nitrogens, for the Glu-Thr peptide bond hydrolysis to occur. The rate of this reaction is maximal at high $\mathrm{pH}$ values, where such a square planar complex predominates.

Figure 5 presents the temperature profile of $k^{1}$, determined at $\mathrm{pH} 9.5$ for temperatures of incubation between 10 and $75^{\circ} \mathrm{C}$. The strict sequence specificity of the reaction was maintained in this broad temperature range. As shown in this figure, $k^{1}$ depended strongly on the temperature. The linear Arrhenius plot of these data $(\mathrm{R}=-0.993, \mathrm{n}=6)$, allowed to estimate the activation energy $E_{\mathrm{a}}=92.0 \mathrm{~kJ}$ $\mathrm{mol}^{-1}$ and activation entropy $\Delta S^{\neq}=208 \mathrm{~J} \mathrm{~mol}^{-1} \mathrm{~K}^{-1}$. The non-catalytic character of the hydrolysis reaction studied here justifies the comparison of the activation energy obtained above with those determined previously for uncatalyzed peptide bond hydrolysis

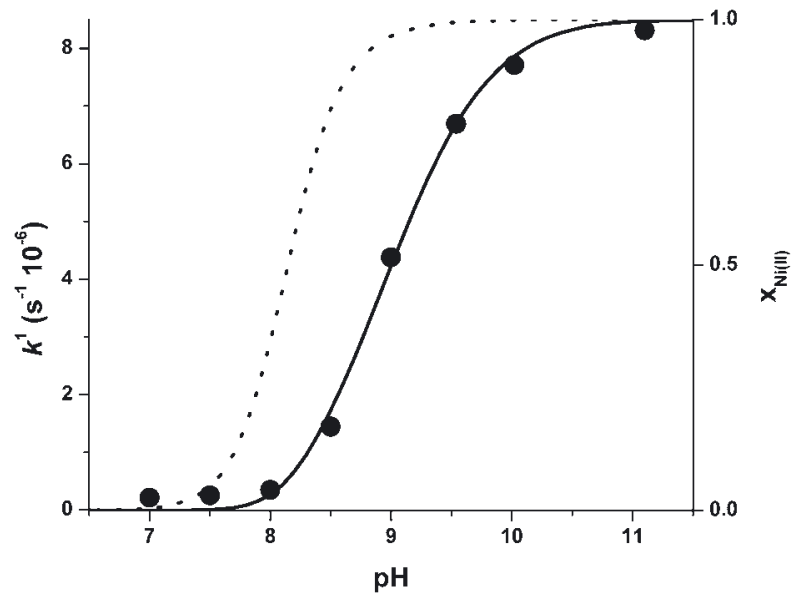

Figure 4. The $\mathrm{pH}$ dependence of the 1 st order rate constant of -Glu-Thr- peptide bond hydrolysis in $1 \mathrm{mM}$ Thr-Glu-Thr-His-His-Lys- $\mathrm{NH}_{2}$ incubated with $1 \mathrm{mM}$ $\mathrm{Ni}\left(\mathrm{NO}_{3}\right)_{2}$ at $25^{\circ} \mathrm{C}$.

The $\mathrm{pH}$ was controlled by $50 \mathrm{mM}$ phosphate buffer and monitored during hydrolysis. The dotted and solid lines represent potentiometry-based $\mathrm{pH}$ profiles of molar fractions of $3 \mathrm{~N}+4 \mathrm{~N}$ and $4 \mathrm{~N}$ complexes, respectively. 
A

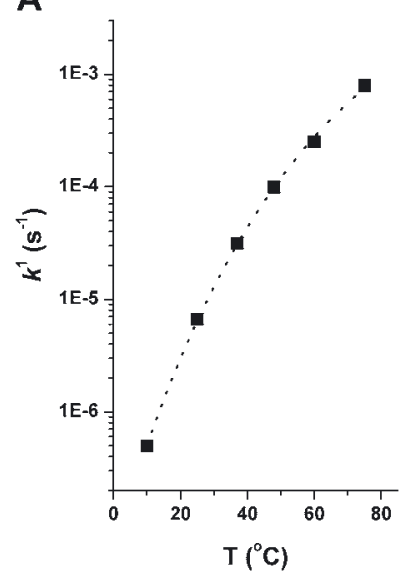

B

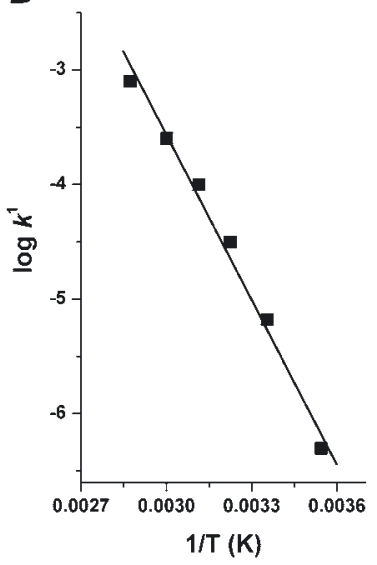

Figure 5. The temperature dependence of the 1st order rate constant of Glu-Thr peptide bond hydrolysis in 1 $\mathrm{mM}$ Ac-Thr-Glu-Thr-His-His-Lys- $\mathrm{NH}_{2}$ incubated in the presence of $1 \mathrm{mM} \mathrm{Ni(II)} \mathrm{at} \mathrm{pH} 9.5$ in a $50 \mathrm{mM}$ phosphate buffer (A), along with the Arrhenius plot of these data and their linear fit (solid line) (B).

under a variety of conditions. A selection of relevant literature data is presented in Table 3. The $E_{\mathrm{a}}$ values at neutral and acidic $\mathrm{pH}$ were similar to that obtained herein, while the alkaline hydrolysis proceeded with a lower activation barrier (Hammel \& Glasstone, 1954; Hartmann et al., 1962; Radzicka \& Wolfenden, 1996; Meyer et al., 2002). The $\Delta S^{\neq}$values determined for simple dipeptides were in the range of about 130-170 $\mathrm{J} \mathrm{mol}^{-1} \mathrm{~K}^{-1}$ (Hartmann et al., 1962; Radzicka \& Wolfenden, 1996). Despite these relatively small differences, the 1st order rate constants for spontaneous processes were substantially lower than that facilitated by $\mathrm{Ni}(\mathrm{II})$ ions. Therefore, the crucial effect introduced by the metal must be related to the effectivity of the bond cleavage once the energy barrier is overcome. It is probably due to a strong increase of $\mathrm{Ni}(\mathrm{II})$ binding constant for the C-terminal reaction product, so called His-3 peptide, compared to the starting complex. This phenomenon is due to a weaker competition of $\mathrm{H}^{+}$ions for the $\mathrm{Ni}(\mathrm{II})$-bound amine nitrogen, present in the hydrolysis product $\left(\mathrm{pK}_{\mathrm{a}} \sim 7-9\right)$, compared to that for the correspond-

Table 3. A review of 1st order rate constants and activation energies for non-catalytic peptide bond hydrolysis, determined under various conditions.

\begin{tabular}{lrll}
\hline Peptide & $k_{1}\left(\mathrm{~s}^{-1}\right)$ & $\begin{array}{l}E_{\mathrm{a}}(\mathrm{kJ} \\
\left.\mathrm{mol}^{-1}\right)\end{array}$ & Conditions \\
\hline Ala-Ala $^{\mathrm{a}}$ & $2.1 \times 10^{-6}$ & $70^{\mathrm{a}}$ & $75^{\circ} \mathrm{C}, 0.1 \mathrm{M} \mathrm{NaOH}$ \\
Gly-Gly $^{\mathrm{b}}$ & $1.8 \times 10^{-5}$ & 80 & $75^{\circ} \mathrm{C}, 2 \mathrm{M} \mathrm{HCl}$ \\
Gly-Gly $^{\mathrm{b}}$ & $9.7 \times 10^{-5}$ & 59 & $75^{\circ} \mathrm{C}, 2 \mathrm{M} \mathrm{NaOH}$ \\
Gly-Gly $^{\mathrm{c}}$ & $1.3 \times 10^{-6}$ & 98 & $120^{\circ} \mathrm{C}, \mathrm{pH} 5$ \\
PA-11 polymer & no data & $81-87$ & $120^{\circ} \mathrm{C}, \mathrm{pH} \mathrm{7}$ \\
Ac-TETHHK-NH $_{2}^{\mathrm{e}}$ & $7.5 \times 10^{-4}$ & 92 & $75^{\circ} \mathrm{C}, \mathrm{pH} \mathrm{9.5}$ \\
\hline
\end{tabular}

${ }^{a}$ Hartmann et al. (1962); $E_{\mathrm{a}}$ values in the $62-80 \mathrm{~kJ} \mathrm{~mol}^{-1}$ range reported for several analogous simple dipeptides; ${ }^{b}$ Radzicka \& Wolfenden (1996); ' Hammel \& Glasstone (1954), E $E_{a}$ value estimated from the published graph; ${ }^{\mathrm{d}}$ Meyer et al. (2002); e this work.

ing amide nitrogen, present in the substrate $\left(\mathrm{p} K_{\mathrm{a}} \sim\right.$ 14-15; Sigel \& Martin, 1982). The broad literature on such complexes indicates that this gain of stability, roughly one million-fold, corresponds to a difference between the above $\mathrm{p} K_{\mathrm{a}}$ values, typically about six $\log$ units (Kozłowski et al., 1999). This notion was confirmed for hydrolyzable serine analogs of the peptide studied (Mylonas et al., 2004b; Mylonas et al., 2005b). Figure 6 depicts the structures of substrate and product of the Thr peptide studied here, along with their spectroscopic parameters, which substantiate the difference in coordination modes. The conversion of the N-terminal amide in the starting $\mathrm{Ni}$ (II) complex into the N-terminal amine complex can thus be treated as a reaction coupled to hydrolysis, which provides additional free energy of about $34 \mathrm{~kJ} \mathrm{~mol}^{-1}$ at $25^{\circ} \mathrm{C}$ and $40 \mathrm{~kJ} \mathrm{~mol}^{-1}$ at $75^{\circ} \mathrm{C}$.

Table 4 compares the rate constants and reaction half-times of several peptides containing the active Ser residue with that containing the active Thr residue. Among these peptides, the $\mathrm{Ni}$ (II) dependent hydrolysis of Ac-Thr-Glu-Ser-His-His-Lys- $\mathrm{NH}_{2}$, Ac-Thr-Ala-Ser-His-His-Lys- $\mathrm{NH}_{2}$ and Ac-Thr-GluSer-Ala-His-Lys- $\mathrm{NH}_{2}$ was studied previously only qualitatively (Mylonas et al., 2002a), and that of the terminally extended peptide Ac-Phe-Thr-Glu-SerHis-His-Lys-Tyr- $\mathrm{NH}_{2}$ was not studied at all.

The rate for the Ac-Thr-Glu-Thr-His-His-Lys$\mathrm{NH}_{2}$ peptide was severalfold higher than that of the

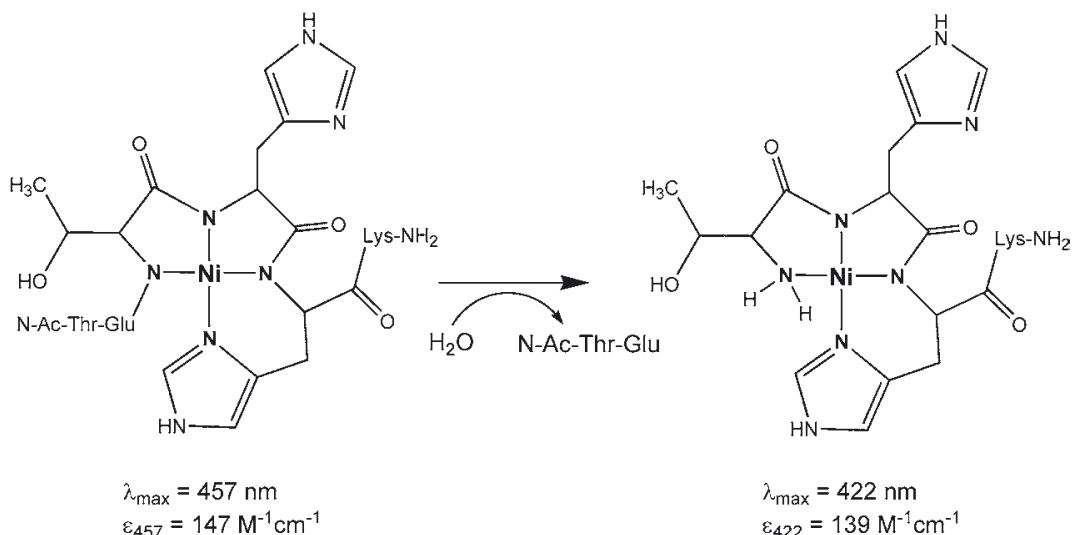

Figure 6. Schematic representation of active square planar $\mathrm{Ni}(\mathrm{II})$ complex (fully deprotonated, $\mathrm{NiH}_{-3} \mathrm{~L}^{2-}$ ) with AcThr-Glu-Thr-His-His-Lys- $\mathrm{NH}_{2}$ and its hydrolysis product.

The conversion of the N-terminal amide donor into the amine results in a change of spectroscopic parameters of these planar complexes. 
Table 4. First order rate constants and corresponding reaction half-times for peptide bond hydrolysis, determined by HPLC at pH 9.5 (25 mM phosphate buffer) and $25^{\circ} \mathrm{C}$, for peptide and $\mathrm{Ni}(\mathrm{II})$ concentrations of $1 \mathrm{mM}$.

The N- and C-terminal hydrolysis products are marked in italic and plain characters, respectively, and the crucial Ser/ Thr residue is marked in bold.

\begin{tabular}{llc}
\hline Peptide & $k^{1}\left(\mathrm{~s}^{-1} \times 10^{-6}\right)$ & $\mathrm{t}_{1 / 2}(\mathrm{~h})$ \\
\hline Ac-Thr-Glu-Ser-His-His-Lys-NH & $2.0 \pm 0.3$ & 96 \\
Ac-Phe-Thr-Glu-Ser-His-His-Lys-Tyr-NH & $8.0 \pm 0.2$ & 24 \\
Ac-Thr-Ala-Ser-His-His-Lys-NH & $4.3 \pm 0.8$ & 44 \\
Ac-Thr-Glu-Ser-Ala-His-Lys-NH & $4.3 \pm 0.5$ & 44 \\
Ac-Thr-Glu-Thr-His-His-Lys-NH & $6.7 \pm 0.7$ & 29 \\
\hline
\end{tabular}

sister Ac-Thr-Glu-Ser-His-His-Lys- $\mathrm{NH}_{2}$ peptide, but slightly lower than that of the serine peptide elongated at both termini with aromatic residues. The serine peptides substituted with alanine residues before and after the Ser residue gave intermediate rate constants. Notably, the comparison of the rates for Ac-Thr-Glu-Ser-His-His-Lys- $\mathrm{NH}_{2}$ and Ac-Thr-AlaSer-His-His-Lys- $\mathrm{NH}_{2}$ indicates that the N-terminal part of the peptide, preceding the Ser residue, had no influence on the course of the reaction. Overall, Table 4 demonstrates that the threonine residue is at least equivalent to serine as a site of $\mathrm{Ni}(\mathrm{II})$-dependent peptide bond hydrolysis in general sequences -Xaa-Thr/Ser-Yaa-His-Zaa-.

\section{CONCLUSIONS}

In the present paper we demonstrated that the peptide containing a threonine residue in the -ThrXaa-His- sequence is susceptible to $\mathrm{Ni}$ (II) dependent hydrolysis at least as much as Ser-containing analogs reported previously. We also demonstrated that this reaction is strictly dependent on the formation of a $4 \mathrm{~N}$ planar $\mathrm{Ni}(\mathrm{II})$ complex of the peptide and determined its activation parameters. The detailed knowledge of $\mathrm{pH}$ and temperature dependence of the rate of hydrolysis obtained in this work provides a strong basis for further studies leading to elucidation of the mechanism of $\mathrm{Ni}(\mathrm{II})$-dependent peptide bond hydrolysis. With respect to $\mathrm{Ni}(\mathrm{II})$ toxicity, the results provided herein expand the range of protein sequences potentially susceptible to $\mathrm{Ni}$ (II) dependent cleavage by those containing threonine residues and provide the basis for correlating the extent of cleavage of histone $\mathrm{H} 2 \mathrm{~A}$ and other hypothetical $\mathrm{Ni}$ (II) hydrolytic targets with temperature and local $\mathrm{pH}$ values. These results will help direct further toxicological studies of $\mathrm{Ni}(\mathrm{II})$ dependent peptide bond hydrolysis.

\section{Acknowledgements}

This research was partially supported by a Marie Curie fellowship of the European Community programme "Metals in biological systems" to A.K. in the laboratory of Professor N. Hadjiliadis, University of Ioannina, under contract no. HPMT-CT-200000203.

We thank Dr Jacek Wójcik (Institute of Biochemistry and Biophysics PAS) for recording the NMR spectra.

\section{REFERENCES}

Bal W, Chmurny GN, Hilton BD, Sadler PJ, Tucker A (1996) Axial hydrophobic fence in highly stable Ni(II) complex of des-angiotensinogen N-terminal peptide. $J$ Am Chem Soc 118: 4727-4728.

Bal W, Lukszo J, Bialkowski K, Kasprzak KS (1998) Interactions of nickel(II) with histones: interactions of $\mathrm{Ni}(\mathrm{II})$ with $\mathrm{CH}_{3} \mathrm{CO}-\mathrm{Thr}-\mathrm{Glu}-\mathrm{Ser}-\mathrm{His}-\mathrm{His}-\mathrm{Lys}_{\mathrm{NH}}$, a peptide modeling the potential metal binding site in the "C-tail" region of histone H2A. Chem Res Toxicol 11: 1014-1023.

Bal W, Liang R, Lukszo J, Lee S-H, Dizdaroglu M, Kasprzak KS (2000a) Ni(II) specifically cleaves the Cterminal tail of the major variant of histone $\mathrm{H} 2 \mathrm{~A}$ and forms an oxidative damage-mediating complex with the cleaved octapeptide. Chem Res Toxicol 13: 616-624.

Bal W, Wójcik J, Maciejczyk M, Grochowski P, Kasprzak KS (2000b) Induction of a secondary structure in the $\mathrm{N}$-terminal pentadecapeptide of human protamine HP2 through Ni(II) coordination. An NMR study. Chem Res Toxicol 13: 823-830.

Chan WC, White PD, eds (2000) Fmoc Solid Phase Peptide Synthesis. A Practical Approach, Oxford University Press, New York.

Fields GB, ed. (1997) Solid Phase Synthesis. Methods Enzymol 289.

Gans P, Sabatini A, Vacca A (1985) SUPERQUAD: An improved general program for computation of formation constants from potentiometric data. J Chem Soc, Dalton Trans 1195-1199.

Hammel EF Jr, Glasstone S (1954) Physicochemical studies of the simpler polypeptides. III. The acid- and basecatalyzed hydrolysis of di-, tri-, tetra-, penta- and hexaglycine. J Am Chem Soc 76: 3741-3745.

Hartmann H, Heintges J, Jung H, Heidberg J (1962) Untersuchungen über die Kinetik der Spaltung von Di- und Tripeptiden. Z Naturforsch 17b: 143-149.

Irving H, Miles MG, Pettit LD (1967) A study of some problems in determining the stoichiometric proton dissociation constants of complexes by potentiometric titrations using a glass electrode. Anal Chim Acta 38: 475-488.

Kaczmarek P, Jeżowska-Bojczuk M, Gatner K, Bal W (2005) Oxidative reactivity of $\mathrm{Cu}$-TESHHK- and its alanine analogues. J Chem Soc Dalton Trans 1985-1988.

Karaczyn AA, Bal W, North SL, Bare RM, Hoang VM, Fisher RJ, Kasprzak KS (2003) The octapeptidic end of the C-terminal tail of histone H2A is cleaved-off in cells exposed to carcinogenic Ni(II). Chem Res Toxicol 16: 1555-1559.

Kozłowski H, Bal W, Dyba M, Kowalik-Jankowska T (1999) Specific structure-stability relations in metallopeptides. Coord Chem Rev 184: 319-346.

Meyer A, Jones N, Lin Y, Kranbuehl D (2002) Characterizing and modeling the hydrolysis of polyamide11 in a $\mathrm{pH} 7$ water environment. Macromolecules 35: 2784-2798. 
Mylonas M, Krężel A, Plakatouras JC, Hadjiliadis N, Bal W (2002a) The binding of $\mathrm{Ni}(\mathrm{II})$ ions to the peptides derived from the metal binding motif of histone H2A. I Chem Soc, Dalton Trans 4296-4306.

Mylonas M, Plakatouras JC, Hadjiliadis N, Krężel A, Bal W (2002b) Potentiometric and spectroscopic studies of the interaction of $\mathrm{Cu}(\mathrm{II})$ ions with the hexapeptides AcThrAlaSerHisHisLysNH ${ }_{2}$, AcThrGluAlaHisHisLysNH ${ }_{2}$ AcThrGluSerAlaHisLysNH ${ }_{2}$ and AcThrGluSerHisAlaLysNH$_{2}$, models of C-terminal tail of histone H2A. Inorg Chim Acta 339: 60-70.

Mylonas M, Krężel A, Plakatouras JC, Hadjiliadis N, Bal W (2004a) Interactions of $\mathrm{Zn}(\mathrm{II})$ ions with three Hiscontaining peptide models of histone H2A. Bioinorg Chem Appl 2: 125-140.

Mylonas M, Plakatouras JC, Hadjiliadis N (2004b) Interactions of $\mathrm{Ni}(\mathrm{II})$ and $\mathrm{Cu}(\mathrm{II})$ ions with the hydrolysis products of the C-terminal -ESHH-motif of histone $\mathrm{H} 2 \mathrm{~A}$ model peptides. Association of the stability of the complexes formed with the cleavage of the -ES-bond. Dalton Trans 4152-4160.

Mylonas M, Krężel A, Plakatouras JC, Hadjiliadis N, Bal W (2005a) Interactions of transition metal ions with
His-containing peptide models of histone H2A. I Mol Liq 118: 119-129.

Mylonas M, Plakatouras JC, Hadjiliadis N, Papavasileiou KD, Melissas VS (2005b) An extremely stable Ni(II) complex derived from the hydrolytic cleavage of the C-terminal tail of histone H2A. J Inorg Biochem 99: 637643.

Radzicka A, Wolfenden R (1996) Rates of uncatalyzed peptide bond hydrolysis in neutral solution and the transition state affinities of proteases J Am Chem Soc 118: 6105-6109.

Raycheba JMT, Margerum DW (1980) Effect of non-coordinative axial blocking on the stability and kinetic behavior of ternary 2,6-lutidine-nickel(II)-oligopeptide complex. Inorg Chem 19: 837-843.

Sigel H, Martin RB (1982) Coordinating properties of the amide bond. Stability and structure of metal ion complexes of peptides and related ligands. Chem Rev 82: 385-426. 